\title{
KARAKTERISTIK DASAR LITERASI DIGITAL DAN RELASI SOSIAL GENERASI MILENIAL BANTEN
}

\author{
Rizki Setiawan \\ Program Studi Pendidikan Sosiologi, Fakultas Keguruan dan Ilmu Pendidikan \\ Universitas Sultan Ageng Tirtayasa \\ rizkisetiawan@untirta.ac.id
}

\begin{abstract}
ABSTRAK
Penelitian ini bertujuan untuk mengeksplorasi karakteristik dasar literasi digital dan relasi sosial generasi milenial di Banten. Penelitian ini menggunakan metode survei. Pertanyaan terkait dengan literasi digital terbagi atas tiga kelompok, yaitu mengenai penggunaan perangkat, strategi membaca, dan strategi verifikasi informasi. Sementara pertanyaan terkait dengan relasi sosial terdiri dari bagaimana informan melakukan interaksi sosial, bagaimana kepeduliannya terhadap pandangan masyarakat terhadap dirinya, dan bagaimana relasi informan dalam kelompok. Hasil penelitian ini menemukan bahwa generasi milenial Banten memiliki karakteristik dasar literasi digital: (1) generasi milenial Banten mengandalkan buku sebagai sumber informasi; (2) bentuk visual informasi mulai dari yang paling disukai generasi milenial Banten ialah video; (3) gaya membaca generasi milenial Banten yang terbanyak adalah dengan menggunakan kata kunci atau fokus tertentu; (4) strategi verifikasi informasi generasi milenial Banten adalah dengan membandingkan sumber. Sementara pada karakteristik relasi sosial generasi milenial Banten ditemukan bahwa generasi milenial Banten lebih menyukai interaksi langsung dalam melakukan interaksi sosial, dan generasi milenial lebih menyukai aktivitas komunal dan aktif dalam kegiatan kelompok. Dengan demikian karakteristik generasi milenial di tingkat lokal Banten tidak sepenuhnya sama dengan karakteristik literasi digital maupun relasi sosial yang menjadi arus utama pandangan masyarakat luas maupun yang dijadikan dasar pengambilan kebijakan. Dengan begitu perlu dilakukan evaluasi secara menyeluruh atas keputusan perubahan yang menyandarkan diri pada generalisasi karakteristik generasi.
\end{abstract}

Kata Kunci: Literasi Digital, Relasi Sosial, Pembangunan Manusia, Generasi Milenial, Sosiologi Pembangunan

\begin{abstract}
This study aims to explore the basic characteristics Banten's millennial generation of digital literacy and social relations. This research uses the survey method. Questions related to digital literacy are divided into three groups, namely regarding the use of devices, reading strategies, and information verification strategies. In contrast, the questions related to social relations consist of how the informant conducts social interaction, how concerned about the public's view of him, and how the informant's connections within the group. The results of this study found that Banten's millennial generation has the basic characteristics of digital literacy: (1) Banten's millennial generation relies on books as a source of information; (2) the visual form of information starting from the most preferred Banten millennial generation is video; (3) Banten's most millennial generation reading style is by using certain keywords or focus; (4) Banten millennial generation information verification strategy is to compare sources. While on the characteristics of Banten millennial generation social relations, it is found that the Banten millennial generation prefers direct interaction in carrying out social interactions, and the millennial generation prefers communal and active activities in group activities. Thus the characteristics of millennial generation at the local level in Banten are not entirely the same as the characteristics of digital literacy and social relations, which are the mainstream of view of the wider community and are used as the basis for policymaking. In this way, it is necessary to conduct a thorough evaluation of the change decisions that rely on generalizing generational characteristics.
\end{abstract}

Keywords: Digital Literacy, Social Relation, Human Development, Millennial Generation, Sociology Of Development 


\section{PENDAHULUAN}

Masyarakat kontemporer tengah menghadapi percepatan laju perubahan sosial yang dipicu internet sebagai lubrikan globalisasi dan evolusi sosial di berbagai sendi kehidupan sosial. Penyebaran kebudayaan antar komunitas bahkan antar bangsa dimungkinkan atas keterbukaan informasi dengan berbagai fasilitas komunikasi digital, ketersediaan transportasi yang semakin banyak dan murah, dan bahkan kemudahan migrasi dengan kebijakan antar negara yang semakin terbuka. Kondisi ini kemudian melahirkan generasi milenial yang ditengarai berbagai kalangan memiliki pemikiran, sikap dan bentuk interaksi sosial yang sama sekali berbeda dengan generasi sebelumnya.

Situasi ini membawa keresahan atas kehidupan sosial keseharian seperti renggangnya relasi sosial antar individu karena terbaginya aktivitas di dua ruang yang sering kali sama sekali berbeda (lingkungan fisik dan lingkungan cyberspace), dan larutnya individu dalam arus kebudayaan yang menjadi trending topic media sosial. Kondisi ini membawa perubahan positif seperti semakin cepat, mudah dan luasnya kepedulian sosial terhadap musibah pada masyarakat tertentu, maupun hal lainnya. Namun situasi ini juga membawa dampak negatif yang setidaknya berupa menurunnya tingkat kepedulian terhadap komunitas di mana ia berada. Ataupun juga dampak yang bersifat negatif dan positif sekaligus sebagaimana yang ditemukan Setiawan (2017) bahwa individu tengah mengalami kondisi perluasan cara dan saluran ekspresi namun secara bersamaan juga tampil ketidakmampuan individu dan masyarakat menghadapi perubahan sosial yang baru ini sehingga menyebabkan semakin terancamnya kebebasan individu di era digital.

Secara sosiologis, masyarakat di era digital memberikan tantangan bagi teori dan praksis keilmuan. Untuk itu telah diupayakan membangun satu cabang keilmuan sosiologi baru, yaitu sosiologi digital. Sebagaimana Lupton (2015 dalam Sutrisno, B. 2017:84) yang mendefinisikan sosiologi digital sebagai cabang sosiologi yang menganalisis praktik sosial di ruang digital dan penggunaan teknologi digital dan data digital untuk penelitian sosiologis.

Penggunaan istilah generasi milenial dalam penelitian ini dilakukan secara longgar, dalam artian tidak terbatas pada rentang waktu sebagaimana diungkap pada teoritisi yang menciptakan istilah ini (lihat tabel 1). Alasannya, penggunaan istilah generasi milenial masih merupakan istilah yang populer dalam kosakata masyarakat Indonesia secara luas yang muncul di media cetak dan digital maupun karya ilmiah untuk menggambarkan generasi muda sekarang ini. Sebagaimana Setiawan (2017) yang menggunakan istilah pribumi digital (native digita) untuk menggambarkan generasi muda Indonesia yang lahir setelah tahun 1995. Maupun Fajriani, S. W., \& Sugandi, Y. S. (2019) 
yang menggunakan terminologi milenial dalam menganalisis masyarakat milenial melalui literatur.

Meskipun kemunculan generasi yang sama sekali baru ini sudah mendapatkan kritik karena dipandang tidak memiliki pembuktian yang kuat, banyak kebijakan pemerintah terutama di bidang pendidikan yang mendasarkan diri untuk mengadaptasi eksistensi generasi baru (Setiawan 2017; Bennet 2008). Keseluruhan situasi ini meningkatkan urgensi untuk melakukan penelitian dasar mengenai bagaimana kapabilitas literasi digital generasi milenial tingkatan lokal Banten sebagai bentuk evaluasi karakteristik generasi milenial.

\section{METODE PENELITIAN}

Tujuan penelitian ini adalah guna mengeksplorasi karakteristik dasar literasi digital dan relasi sosial generasi milenial di Banten. Penelitian ini menggunakan metode survei bersifat kualitatif melalui wawancara mendalam di mana informan senantiasa diminta untuk menjelaskan setiap jawaban yang diberikan.

Penelitian ini menanyakan serangkaian hal terkait dengan literasi digital dan relasi sosial kepada informan. Pertanyaan terkait dengan literasi digital terbagi atas tiga kelompok, yaitu mengenai penggunaan perangkat, strategi membaca, dan strategi verifikasi informasi. Sementara pertanyaan terkait dengan relasi sosial terdiri dari bagaimana informan melakukan interaksi sosial, bagaimana kepedulian informan terhadap pandangan masyarakat terhadap dirinya, dan bagaimana relasi informan di dalam kelompok.

Penelitian ini dilaksanakan pada Agustus sampai dengan Oktober 2018 dengan melibatkan 68 informan yang merupakan siswa SMA kelas XI dan XII di 4 wilayah Provinsi Banten (Kota Cilegon, Kabupaten Tangerang, Kota Serang, dan Kabupaten Serang). Pemilihan informan menggunakan teknik purposive sampling, yaitu dengan mempertimbangkan karakteristik khusus yang telah ditetapkan peneliti : (1) wilayah tempat tinggal; (2) tingkat pendidikan; (3) jenis kelamin; (4) prestasi di sekolah; (5) keaktifan organisasi, serta; (6) pekerjaan dan; (7) penghasilan orang tua.

\section{KERANGKA TEORI/KONSEP}

\section{Literasi Digital Generasi Milenial}

Istilah "generasi milenial” pertama kali diberikan oleh Howe, N., \& Strauss, W.(2000 dan 2003), dimana terdapat juga istilah lainnya yang muncul lebih dulu seperti "generasi net" (Oblinger \& Oblinger, 2005; Tapscott, 1998) maupun “pribumi digital” (Presnky, 2001a) (selengkapnya lihat 
tabel 1). Di Indonesia sendiri, generasi millennial dimaknai berbagai kalangan sebagai individu yang dilahirkan antara tahun 1981 sampai dengan tahun 2000 (Budiati 2018: 16-17).

Tabel 1. Istilah Generasi

\begin{tabular}{|c|c|c|c|c|c|}
\hline Sumber & Istilah Generasi & & & & \\
\hline $\begin{array}{l}\text { Howe and } \\
\text { Strauss } \\
(2000)\end{array}$ & $\begin{array}{l}\text { Generasi Sunyi } \\
(1925-1943)\end{array}$ & $\begin{array}{l}\text { Generasi } \\
\text { Boomers } \\
(1943-1960)\end{array}$ & $\begin{array}{l}\text { Generasi } \\
\text { ke-13 } \\
(1961- \\
1981)\end{array}$ & $\begin{array}{l}\text { Generasi } \\
\text { Millenial(1982-2000) }\end{array}$ & - \\
\hline $\begin{array}{l}\text { Lancaster } \\
\text { and Stillman } \\
\text { (2002) }\end{array}$ & $\begin{array}{l}\text { Tradisionalis } \\
(1900-1945)\end{array}$ & $\begin{array}{l}\text { Baby } \\
\text { Boomers } \\
(1946-1964)\end{array}$ & $\begin{array}{l}\text { Xers } \\
(1965- \\
1980)\end{array}$ & $\begin{array}{l}\text { Millenial/ Echo / } \\
\text { Boomer; Y; Baby } \\
\text { Busters; Next (1981- } \\
\text { 1999) }\end{array}$ & - \\
\hline $\begin{array}{l}\text { Oblinger } \\
\text { and } \\
\text { Oblinger } \\
(2005)\end{array}$ & $\begin{array}{l}\text { Matures } \\
(<1946)\end{array}$ & $\begin{array}{l}\text { Baby } \\
\text { Boomers } \\
(1947-1964)\end{array}$ & $\begin{array}{l}\text { Gen-Xers } \\
(1965- \\
1980)\end{array}$ & $\begin{array}{l}\text { Gen-Y; NetGen; } \\
\text { Millennial (1981- } \\
\text { 1995) }\end{array}$ & $\begin{array}{l}\text { Post- } \\
\text { Millennials } \\
(1995- \\
\text { Sekarang) }\end{array}$ \\
\hline $\begin{array}{l}\text { Martin and } \\
\text { Tulgan } \\
(2002)\end{array}$ & $\begin{array}{l}\text { Sunyi(1925- } \\
1942)\end{array}$ & $\begin{array}{l}\text { Baby } \\
\text { Boomers } \\
(1946-1960)\end{array}$ & $\begin{array}{l}\mathrm{X}(1965- \\
1977)\end{array}$ & $\begin{array}{l}\text { Millennials (1978- } \\
\text { 2000) }\end{array}$ & - \\
\hline $\begin{array}{l}\text { Tapscott } \\
(1998)\end{array}$ & - & $\begin{array}{l}\text { Baby } \\
\text { Boom } \\
(1946-1964)\end{array}$ & $\begin{array}{l}\mathrm{X}(1965- \\
1975)\end{array}$ & Digital (1976-2000) & - \\
\hline $\begin{array}{l}\text { Zemke et al. } \\
(2000)\end{array}$ & $\begin{array}{l}\text { Veteran (1922- } \\
\text { 1943) }\end{array}$ & $\begin{array}{l}\text { Baby } \\
\text { Boomers } \\
(1943-1960)\end{array}$ & $\begin{array}{l}\text { Gen-Xers } \\
(1960- \\
1980)\end{array}$ & Nexters (1980-1999) & - \\
\hline $\begin{array}{l}\text { Presnky } \\
(2001)\end{array}$ & Imigran Digital & <1980) & & $\begin{array}{l}\text { Pribumi Digital } \\
(1980-1994)\end{array}$ & - \\
\hline
\end{tabular}

Sumber : diolah dari Oh, Eunjung, \& Thomas C. Reeves. (2013: 819-828)

Kemudian mengenai istilah literasi digital pertama kali digunakan oleh Gilster (1997), dimana pendefinisian ini dilakukan jauh sebelum youtube, facebook, maupun twitter diciptakan dan digunakan banyak orang. Gilster mendefinisikannya dalam kerangka pendidikan dengan mengakui keunikan dasar internet yang revolusioner dan melakukan identifikasi seperangkat keterampilan informasi tertentu (seperti evaluasi dan pencarian) pada siswa yang melek digital dalam mengakses informasi teks dan multimedia yang ditemukan di internet dan terletak dalam konteks pembelajaran formal berbasis sekolah (Meyers, E. M., Erickson, I., \& Small, R. V. 2013). Sejak diperkenalkan, selain istilah "literasi digital" banyak juga digunakan istilah lain seperti literasi abad ke-21, literasi internet, literasi informasi, literasi ICT, literasi media baru, literasi komputer, dan pemahaman membaca daring (Online Reading Comprehension disingkat ORC) (Osterman 2012).

Definisi literasi di Indonesia juga telah mengalami perkembangan sebagai respon atas perubahan sosial luas yang terutama disebabkan oleh digitalisasi berbagai bidang kehidupan. Dimana pada era sebelumnya literasi terbatas pada kapabilitas individu untuk membaca, menulis, dan 
memahami huruf-huruf yang terangkai menjadi kata, kalimat dan akhirnya suatu tulisan secara utuh. Definisi Literasi sebagaimana dimuat KBBI (Kamus Besar Bahasa Indonesia) daring, yaitu: (i) kapabilitas menulis dan membaca; (ii) pengetahuan atau kecakapan dalam bidang atau aktivitas tertentu: -- komputer, dan; (iii) kemampuan individu dalam mengolah informasi dan pengetahuan untuk kecakapan hidup. Sementara digital memiliki makna "berhubungan dengan angka-angka untuk sistem perhitungan tertentu; berhubungan dengan penomoran”. Definisi literasi yang dimuat KBBI ini (terutama poin ii) semakin dekat dengan definisi literasi digital sebagai respon atas kebutuhan keterampilan baru abad 21 berupa "melek huruf digital".

Salah satu penelitian mengenai literasi digital dilakukan oleh Stefani, S. Nurbani, \& Badarrudin (2017) yang menemukan terdapatnya korelasi positif dalam skala sedang antara literasi digital dan pembukaan diri di media sosial. Dengan kata lain, generasi milenial dengan literasi digital yang baik memiliki pemahaman baik terhadap konsekuensi atas aktivitasnya di media sosial.

Respon atas kemunculan istilah ini juga berupa pendefinisian seperangkat keterampilan yang mencerminkan literasi digital oleh beragam kalangan. Satu diantaranya ialah Yoram EshetAlkalai (Eshet-Alkalai, 2004; Eshet-Alkalai dan Chajut, 2009) yang menyusun enam keterampilan literasi digital, yaitu: (i) literasi fotovisual (photo-visual literacy) yang merupakan kemampuan untuk bekerja efektif dengan lingkungan digital, seperti antarmuka pengguna, itu menggunakan komunikasi grafis; (ii) literasi reproduksi (reproduction literacy) yang merupakan kemampuan untuk menciptakan karya seni dan tulisan yang otentik, bermakna dengan mereproduksi dan memanipulasi teks digital yang sudah ada, visual dan potongan audio; (iii) literasi informasi (information literacy) yang merupakan kemampuan untuk mengonsumsi informasi secara kritis dan memilah yang salah dan bias informasi; (iv) literasi beragam sumber / bercabang (branching literacy) yang merupakan kemampuan untuk membangun pengetahuan dengan navigasi non linier melalui domain pengetahuan, seperti di Internet dan lingkungan media; (v) literasi sosial emosional (socio-emotional literacy) yang merupakan kemampuan untuk berkomunikasi secara efektif dalam platform komunikasi online seperti kelompok diskusi dan ruang obrolan; dan (vi) keterampilan berpikir waktu-nyata (real-time thinking skill) yang merupakan kemampuan untuk memproses dan mengevaluasi volume informasi yang besar secara real time, seperti di game komputer dan ruang obrolan.

Penelitian ini melihat karakteristik dasar literasi digital melalui enam aspek, yaitu: (i) mencari tahu mengenai perangkat yang digunakan informan dalam aktivitas membaca, menulis dan memahami sesuatu; (ii) dengan mencari tahu media yang disukai oleh informan; (iii) mencari tahu teknik membaca yang digunakan informan; (iv) dengan mencari tahu bagaimana informan mengetahui kebenaran suatu informasi yang didapatkannya. 


\section{Relasi Sosial Generasi Milenial}

Relasi sosial telah lama menjadi isu sentral sosiologi, mulai dari Marx (1987/1967:72) yang mengungkap relasi sosial yang dideterminasi oleh sistem produksi dalam masyarakat yang mana dalam kapitalisme relasi sosial tereifikasi menjadi relasi antar barang, Durkheim (1913/1984) yang mencermati ikatan sosial masyarakat dalam menjalin relasi sosial yang berbeda antara masyarakat modern dengan masyarakat tradisional (dengan istilah solidaritas organik dan solidaritas mekanik), sampai dengan Weber (1946) yang mengamati tindakan sosial yang bermakna merasa resah akan mengenai bagaimana sifat impersonal birokrasi merubah relasi sosial masyarakat modern, maupun Simmel (1972:72) yang melihat uang sebagai simbol abstrak relasi sosial. Bahkan secara umum, sebagaimana diungkap Stolley (2005:2), sosiologi dapat didefinisikan sebagai ilmu untuk melakukan studi ilmiah mengenai dinamika, struktur, interaksi, dan perilaku kolektif dari suatu relasi sosial.

Dalam perkembangannya di era revolusi industri 4.0, relasi sosial di masyarakat ditengarai mendapati perubahan yang signifikan. Melalui teknologi yang berpadu dengan konektivitas internet, ruang dan waktu tak lagi menjadi batasan bagi individu dalam melakukan interaksi sosial dalam jalinan relasi sosial keseharian (Setiawan 2019: 98). Beberapa temuan penelitian menunjukkan terjadinya perubahan bentuk relasi sosial. Seperti Turkle (2011) yang menemukan bentuk baru relasi sosial di mana individu saling bertemu secara fisik tapi bersamaan dengan itu ia juga melakukan kegiatan yang tidak memiliki keterkaitan dengan lingkungan fisiknya. Terlebih individu juga lebih banyak melakukan Interaksi dan relasi sosial pada ruang cyber dibandingkan di lingkungan fisik. Kondisi ini kemudian menghasilkan keterlekatan yang kuat antara individu dengan teknologi, terutama dalam hal ini adalah telepon pintar.

Mengenai bagaimana relasi sosial terjalin melalui interaksi dikembangkan sosiolog Turner, J. H. (2002) yang mengembangkan teori sosiologi perilaku interpersonal tatap muka. Teori ini merupakan rekonstruksi konseptual pemikir sebelumnya seperti George Herbert Mead, Sigmund Freud, Alfred Schutz, Émile Durkheim, dan Erving Goffman. Sebagai upaya membangun grand theory mikrodinamika yang mencoba menangkap sifat interpersonal perilaku, Turnet mengungkap prinsip-prinsip perilaku interpersonal yang terdapat dalam interaksi sosial, yaitu sebagai berikut: dinamika emosional, dinamika motivasi, normalisasi dinamika, dinamika peran, dinamika status, dinamika ekologis, dinamika demografis, dan dinamika keterlekatan (embedding dynamics) (Turner 2002: 230-251). 
Sejalan dengan itu, penelitian ini akan melihat bagaimana relasi sosial generasi milenial Banten dengan mencari tahu bentuk interaksi sosial dalam keseharian dan juga bagaimana aktivitas mereka dalam relasi kelompok.

\section{PEMBAHASAN}

Informan yang terlibat dalam penelitian ini dipilih dengan mempertimbangkan karakteristik khusus yang telah ditetapkan peneliti dengan tujuan dapat menggambarkan kondisi sosial informan. Jumlah informan yang terlibat adalah sebanyak 68 orang dengan komposisi sebagai berikut:

1) Tinggal di Kota Cilegon (23,5\%), Kabupaten Tangerang (26,5\%), Kota Serang (23,5\%), Kab. Serang (26,5\%);

2) Merupakan siswa SMA kelas XI (45,6\%) dan XII (54,4\%);

3) Jenis kelamin laki-laki (45,6\%) dan perempuan (54,4\%);

4) Masuk peringkat 10 besar (48,5\%) dan tidak termasuk peringkat 10 besar (51,5\%);

5) Aktif sebagai pengurus organisasi $(52,9 \%)$ dan sebagai anggota atau tidak aktif organisasi $(47,1 \%)$.

6) Orangtua memiliki penghasilan kurang dari 3 juta (32,4\%), antara 3 juta sampai 6 juta $(47,1 \%)$ dan lebih dari 6 juta $(20,6 \%)$, dan;

7) Pekerjaan orangtua PNS (20,6\%), Karyawan (30,9\%), Pekerja Mandiri (30,9\%) dan Pengusaha $(17,6 \%)$.

Pembahasan hasil penelitian akan dibagi menjadi dua. Pertama ialah mengenai literasi digital generasi milenial Banten yang akan membahas temuan mengenai: (i) perangkat yang digunakan dalam aktivitas membaca, menulis dan memahami sesuatu; (ii) media yang disukai; (iii) teknik membaca yang digunakan, dan; (iv) bagaimana mekanisme verifikasi informasi dilakukan. Kedua ialah mengenai relasi sosial generasi milenial Banten yang akan membahas bentuk interaksi sosial dalam keseharian dan juga bagaimana aktivitas mereka dalam relasi kelompok.

\section{A. Literasi Digital Generasi Milenial Banten}

\section{Buku Masih Diandalkan Generasi Milenial Banten}

Pada bagian pertama, hasil penelitian menunjukkan konsistensi penggunaan perangkat dalam aktivitas membaca, menulis dan memahami. Penelitian ini menghasilkan temuan yang berbeda dengan berbagai pandangan bahwa generasi milenial tidak lagi menggunakan cara konvensional seperti membaca melalui koran atau buku dan menonton televisi, namun lebih menggunakan smartphone, tablet ataupun komputer (Oblinger, D., dkk 2005 :15.12; Budiati, I. (dkk) 2018:18). Sebagian besar informan masih mengandalkan buku dalam aktivitas membaca (56\%), menulis (77\%), dan memahami (60\%). Perangkat yang menjadi penggunaan kedua ialah smartphone, yang 
digunakan untuk membaca (38\%), menulis (16\%), dan memahami (28\%). Sementara perangkat digital masih belum menjadi perangkat utama, dimana jika jawaban penggunaan perangkat digital (tablet, komputer (PC) / laptop, dan smartphone) digabung hanya sebesar: membaca (46\%), menulis (33\%), dan memahami (40\%) (diagram 1).

Terdapat beberapa alasan informan lebih menyukai buku, di antaranya ialah: (i) isi buku dianggap sudah nyata (realitas telah divalidasi secara ilmiah) dan tepat; (ii) telah terbiasa membaca buku dan membuat ringkasan dengan menuliskannya di buku tulis; (iii) adanya pembatasan penggunaan media elektronik baik di sekolah maupun keluarga. Buku masih dianggap memiliki keunggulan tersendiri dibandingkan perangkat digital sebagaimana diungkap salah satu informan:

"Kalau membaca saya lebih senang di buku, menulis juga masih senang di buku dan juga memahami saya lebih suka di buku. Meskipun bahasanya baku tapi itu bisa lebib menambah pengetabuan literasi dan kosakata saya."
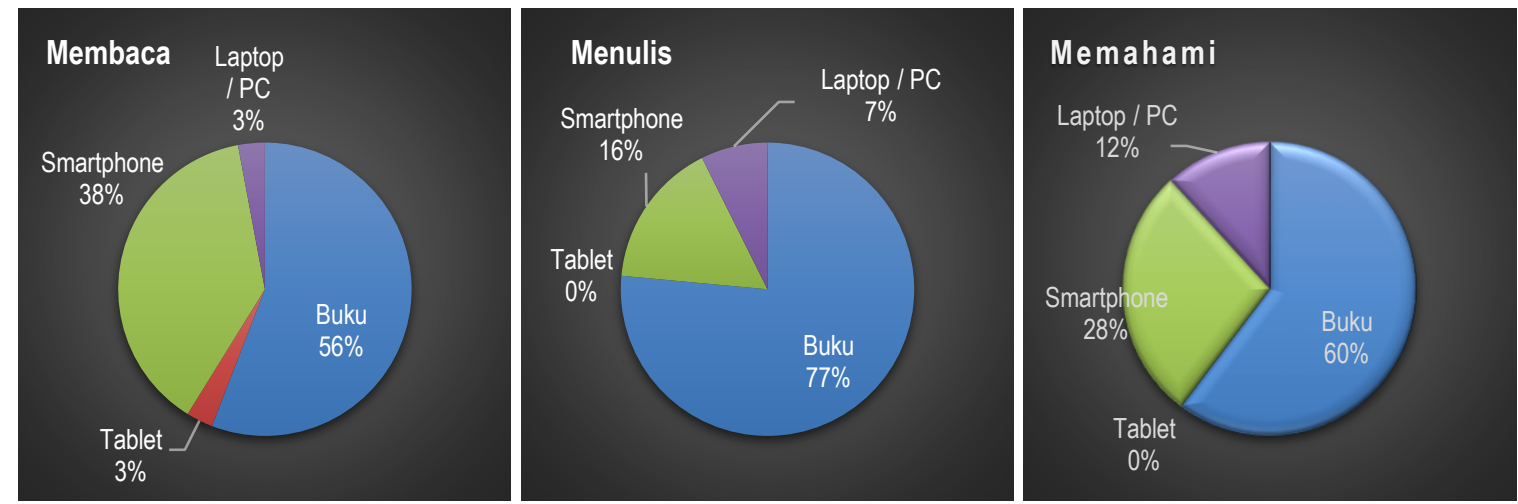

Diagram 1. Penggunaan Perangkat Membaca, Menulis dan Memahami Sumber : Penelitian, 2018

\section{Generasi Milenial Banten Lebih Menyukai Media Video}

Bagian kedua ialah mengenai jenis media yang disukai oleh generasi milenial (teks, grafik/diagram, gambar, video, dan lainnya). Hasil penelitian menunjukkan bahwa lebih banyak generasi milenial yang menyukai video dibandingkan dengan media lainnya. Di mana urutan media mulai dari yang paling disukai adalah video (42,6\%), artikel/teks (33,8\%), gambar (14,7\%), grafik / diagram (1,5\%). Sementara pilihan lainnya sebesar 7,4\%, di mana informan yang memilih jawaban ini dikarenakan mereka lebih menyukai untuk mendengarkan penjelasan secara langsung oleh orang-orang yang lebih mengetahui suatu informasi/pengetahuan (Grafik 1).

Temuan ini sejalan dengan Oblinger, D., dkk (2005:25) yang mengungkap bahwa generasi milenial (Oblinger menggunakan istilah Net Gen) tumbuh dan berkembang dengan akses yang mudah ke teknologi, mampu secara intuitif mengoperasikan beragam perangkat TI dan navigasi 
Internet. Meskipun merasa nyaman secara langsung beraktivitas dengan teknologi tanpa memerlukan buku pedoman, pemahaman mereka mengenai teknologi atau kualitas sumber mungkin tidak mendalam. Mereka juga lebih melek secara visual dari generasi sebelumnya; banyak yang mengekspresikan diri menggunakan gambar. Mereka dapat menyatukan gambar, teks, dan suara secara alami. Kemampuan mereka untuk berpindah antara yang nyata dan yang virtual itu seketika, memperluas kemampuan baca tulis mereka jauh melampaui teks. Namun begitu, situasi ini juga dapat berimplikasi negatif, di mana ketersediaan media visual menyebabkan kurang berkembangnya literasi teks generasi milenial.

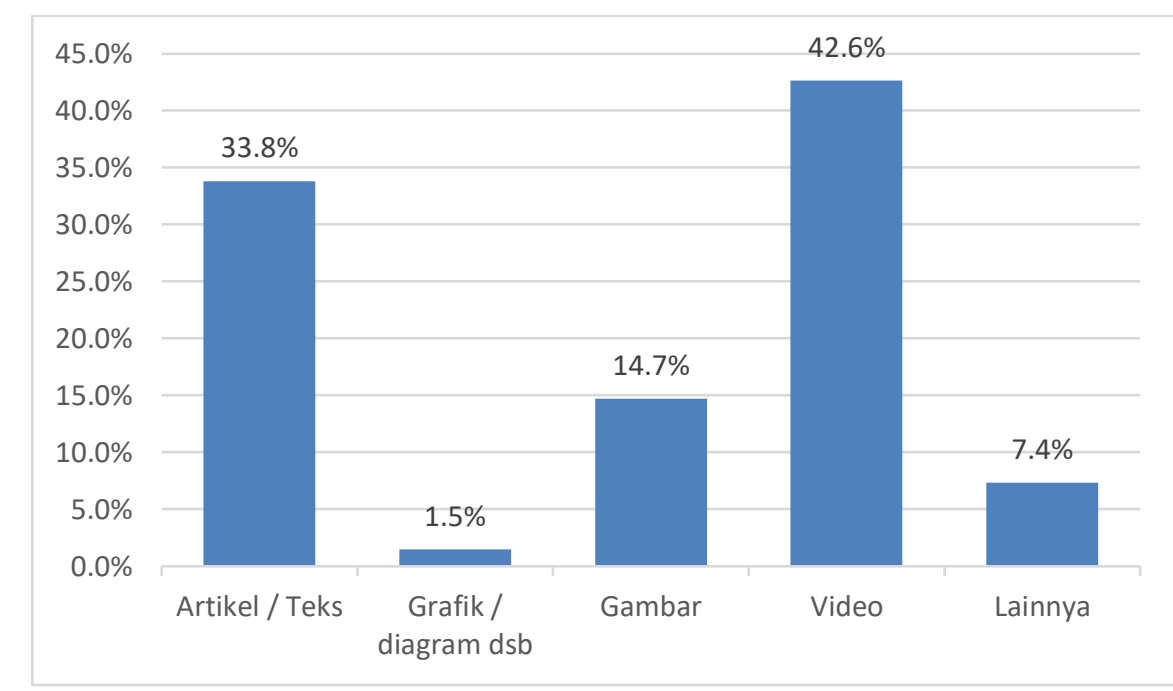

Grafik 1. Jenis Media yang Disukai

Sumber : Penelitian, 2018

\section{Strategi Membaca Generasi Milenial Banten: Membaca dengan Kata Kunci}

Pada bagian ketiga yang mencari strategi membaca, yaitu bagaimana cara generasi milenial membaca artikel (baik di buku, koran/majalah maupun di website). Penelitian menemukan bahwa generasi milenial Banten lebih memilih untuk membaca artikel maupun buku dengan menggunakan kata kunci atau fokus tertentu (50\%). Di mana gaya membaca sekilas dengan cepat ditemukan pada 9\% informan dan gaya membaca dengan seksama dari awal sampai selesai sebesar $41 \%$ informan. Kondisi ini tampak memiliki linieritas dengan penggunaan smartphone sebagai perangkat terpopuler kedua setelah buku, karena dengan menggunakan smartphone pengguna dapat melakukan pencarian kata kunci dengan mudah dan cepat (lihat Grafik 2).

Temuan ini sejalan dengan Manuel, K. (2002: 201) dan Oblinger, D., dkk (2005) yang menemukan bahwa generasi millennial lebih sering membaca melalui website, di mana mereka lebih seperti melakukan pemindaian (membaca cepat, dapat dengan kata kunci) ketimbang membaca. Beberapa kalangan melakukan spekulasi dengan menempatkan tautan di web telah

IGI | SGSIOGLLBAL : Jurnal Pemikiran dan Penelitian Sosiologi, Vol. 4, No. 2, Juni 2020 
mengubah cara orang memproses informasi tekstual. Alih-alih menyelesaikan paragraf yang dibaca, subjek sudah beralih ke bagian lain untuk mendapatkan informasi lebih lanjut.

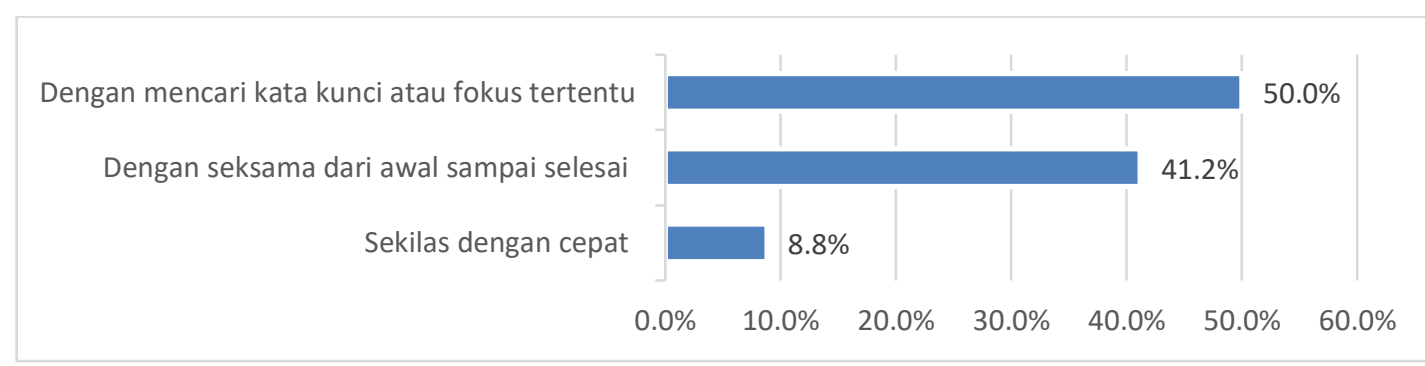

Grafik 2. Strategi Membaca

Sumber : Penelitian, 2018

\section{Strategi Verifikasi Informasi Generasi Milenial Banten: Membandingkan Sumber}

Bagian ketiga perihal bagaimana cara verifikasi kebenaran informasi, penelitian ini memberikan pertanyaan terbuka yang kemudian diolah dengan kategorisasi jawaban untuk menghasilkan data visual yang ringkas. Hasil penelitian menunjukkan terdapat 30,9\% siswa yang mengetahui kebenaran informasi dari internet dengan membandingkan beberapa sumber. Kategori ini terdiri dari upaya mengecek kebenaran informasi melalui browsing di internet dan mencarinya di berita televisi. Terdapat juga yang memperkuat informasi dengan googling ke sumber terpercaya, ke perpustakaan, bertanya pada guru, maupun dengan menunggu informasi dibahas oleh ahli.

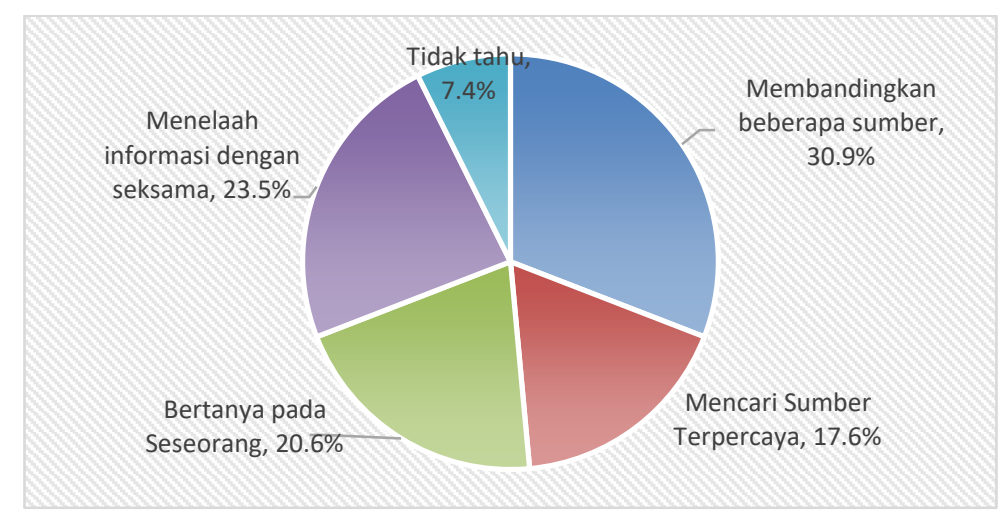

Diagram 2. Strategi Verifikasi Informasi

Sumber : Penelitian, 2018

Pada kategori jawaban mencari dari sumber terpercaya terdapat 17,6\% siswa, di mana kategori ini terdiri dari mengecek kebenaran suatu informasi dengan menelusuri kebenarannya melalui buku maupun situs-situs besar dan populer, seperti di antaranya; sindonews, detikcom, liputan6, kompas, tempo, dan lainnya. Sementara Pada kategori jawaban dengan bertanya pada seseorang terdapat 20,6\% informan, di mana jawaban terdiri dari dengan bertanya pada teman, orang tua, 
guru, orang yang bersangkutan, maupun orang lainnya yang dianggap lebih mengetahui ataupun lebih berpengalaman mengenai hal tersebut.

Kategori jawaban dengan menelaah informasi dengan seksama terdapat 23,5\% informan, di mana jawaban terdiri dari dengan menelaah informasi dengan seksama dengan melihat sumbernya secara langsung maupun melihatnya secara langsung. Kemudian juga dengan meneliti isi informasi baik diksi maupun data yang tersedia, serta membaca komentar warganet terhadap informasi tersebut dengan cermat. Selain itu, terdapat juga informan yang tidak mengetahui cara mengetahui kebenaran informasi dari internet, yaitu sebesar 7,4\%.

Dengan demikian, hasil penelitian menunjukkan bahwa literasi digital generasi milenial Banten memiliki karakteristik dasar literasi digital sebagai berikut: (1) generasi milenial Banten mengandalkan buku sebagai sumber informasi; (2) bentuk visual informasi mulai dari yang paling disukai generasi milenial Banten ialah video; (3) gaya membaca generasi milenial Banten yang terbanyak adalah dengan menggunakan kata kunci atau fokus tertentu; (4) strategi verifikasi informasi generasi milenial Banten adalah dengan membandingkan sumber.

Karakteristik ini membawa kelebihan dan juga tantangan sekaligus. Karakteristik mengandalkan buku sebagai sumber informasi dan juga kapabilitas verifikasi informasi yang kuat memiliki keuntungan berupa tingginya akurasi informasi yang didapatkan. Namun demikian, ketika ditelisik lebih jauh, literasi teks yang dimiliki cukup rendah yang ditunjukkan dengan tingginya preferensi media informasi video dan juga gaya membaca dengan menggunakan kata kunci maupun membaca sekilas dengan cepat.

Penggunaan perangkat digital memiliki kelemahan dan potensi tersendiri di era digital sekarang ini. Pemanfaatan perangkat digital yang terkoneksi internet dapat memperluas akses informasi dan batasan ruang dan waktu sebagaimana didapatkan pada media konvensional, namun di sisi lain media digital juga memiliki kelemahan berupa akurasi informasi yang abu-abu dikarenakan kemudahan berbagi informasi untuk semua orang dari semua kalangan. Dengan demikian, tantangan ke depan yang dihadapi generasi milenial Banten adalah bagaimana mereka dapat memberdayakan teknologi yang tersedia dalam mengakses informasi yang lebih luas dengan kapabilitas literasi teks dan literasi media yang memadai.

\section{B. Relasi Sosial Generasi Milenial Banten}

\section{Interaksi Sosial Generasi Milenial Banten: Interaksi Langsung}

Penelitian ini menemukan bahwa bentuk interaksi sosial generasi milenial Banten berbeda dengan beberapa pemikiran maupun hasil penelitian selama ini, seperti Oblinger \& Oblinger

163 | SGSIOGLOBAL : Jurnal Pemikiran dan Penelitian Sasiolagi, Vol. 4, No. 2, Juni 2020 
(2005: 2.5), Ali, H. dkk (2017:20), Budiati, I. dkk (2018:23), Barni, M. (2019: 103-104) dan lainnya yang mengungkap bahwa salah satu ciri generasi milenial adalah senantiasa terhubung dengan internet (connected). Ali, H., dkk. (2017:23- 26) juga menemukan bahwa generasi milenial tidak dapat melepaskan diri dari aplikasi pesan instan dan media sosial serta mengakses Internet setiap saat. Mereka memiliki preferensi untuk melakukan komunikasi melalui internet ketimbang melakukan komunikasi atau interaksi langsung (Fatmawati 2019: 127). Singkatnya, kebutuhan terkoneksi internet menyamai kebutuhan pokok.

Interaksi Sosial Generasi milenial Banten dibangun pada perjumpaan secara fisik. Ini dapat dilihat dari hasil penelitian mengenai bagaimana cara mereka berinteraksi dalam keseharian, ketika belajar dengan guru maupun teman, dan bagaimana bentuk hubungan yang lebih bermakna bagi dirinya. Dalam keseharian, mereka lebih sering melakukan interaksi dengan tatap muka (82\%), yang diikuti dengan mengirim pesan melalui internet (pesan instan) sebanyak 10,3\% informan, dan melalui Short Message Service (SMS) sebanyak 1,5\% informan. Sementara itu pilihan yang disediakan namun tidak menjadi cara mereka untuk melakukan interaksi sosial keseharian ialah melalui telepon, email dan video call.
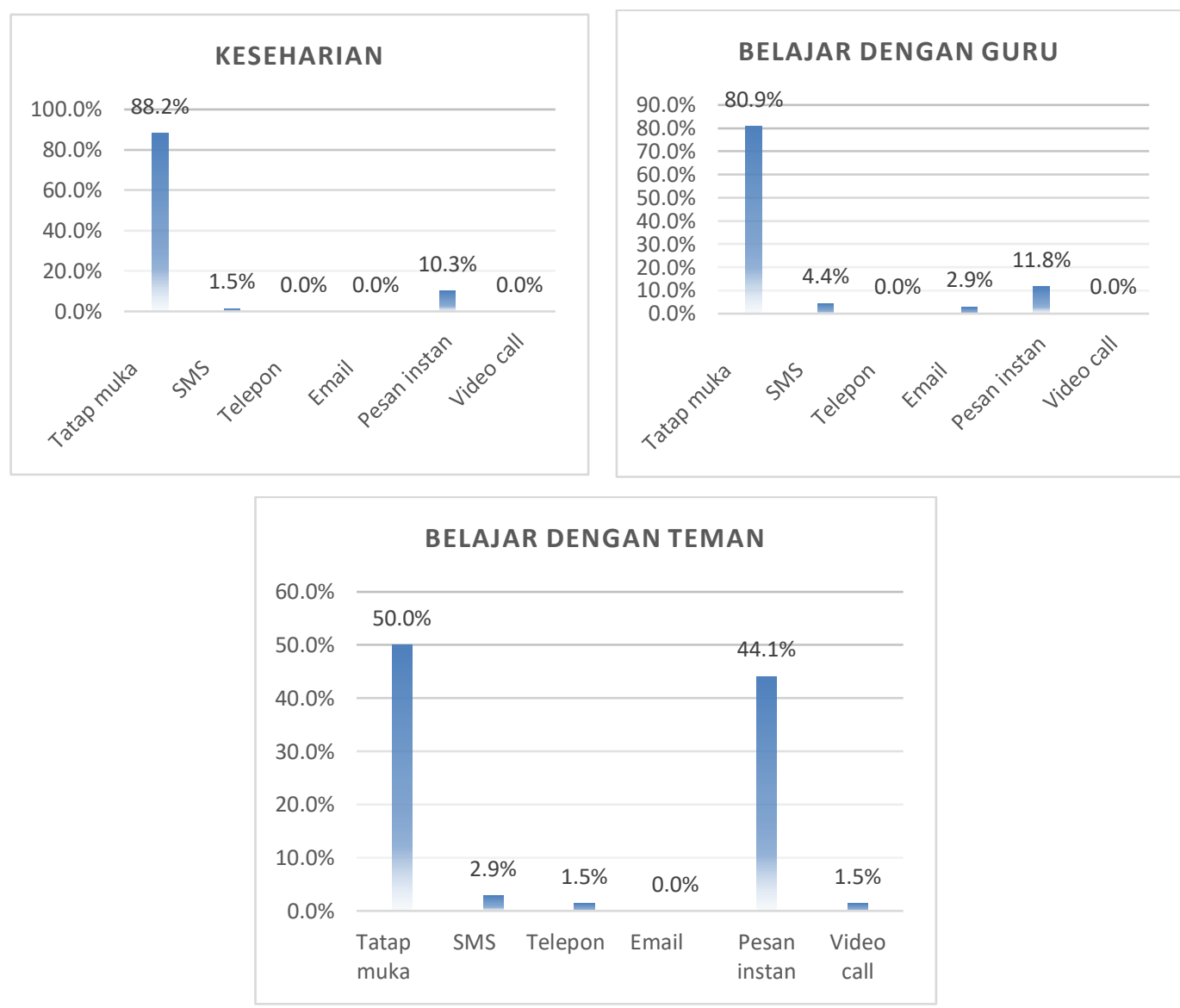

Grafik 3. Interaksi Sosial dalam Keseharian dengan Guru dan Teman Sumber : Penelitian, 2018 


\section{Rizki Setiawan}

Mengenai bentuk interaksi sosial dalam kaitan dengan pembelajaran dengan guru maupun dengan teman yang menunjukkan hasil yang tidak jauh berbeda. Ketika menghubungi guru, mereka lebih menyukai untuk bertemu langsung (80,9\%). Cara menghubungi guru dengan menggunakan media SMS sebanyak 4,4\%, email sebanyak 2,9\%, pesan instan 11,8\%, dan tidak ada yang menjawab melakukan komunikasi melalui telepon dan video call.

Selanjutnya dalam kaitan berhubungan dengan teman, juga didominasi oleh perjumpaan secara langsung (50\%). Sementara cara lain seperti SMS sebanyak 2,9\%, telepon 1,5\%, pesan instan $(44,1 \%)$, video call $1,5 \%$, dan tidak ada yang menggunakan email untuk berhubungan dengan temannya.

Banyaknya informan yang memilih untuk menjalin relasi sosial dengan tatap muka secara langsung disebabkan oleh beberapa alasan, diantaranya: (i) relasi sosial informan masih terikat dengan lingkungan fisik, dengan kata lain baik teman, guru maupun keluarga berada di satu wilayah yang sama; (ii) bertemu langsung dianggap sebagai cara paling efektif dalam melakukan komunikasi maupun mendapatkan informasi; (iii) lokasi yang berdekatan dan intensitas pertemuan dengan lingkungan yang cukup tinggi membuat bertemu langsung dianggap sebagai interaksi sosial berbiaya murah, dan bahkan gratis jika dibandingkan dengan menggunakan teknologi yang harus mengeluarkan biaya untuk pulsa maupun kuota internet. Sementara penggunaan media teknologi sebagai perantara interaksi sosial hanya dilakukan ketika pertemuan langsung tidak memungkinkan dilakukan, sebagaimana yang dikatakan informan:

"saya bersosialisasi di keseharian dengan teman baiknya sebenarnya bertemu langsung dan bertatap muka, karena dengan hal demikian silaturahmi antar teman bisa terjalin dengan sangat baik, kemudian melalui pesan instan (wa, line) diperlukan ketika keadaan untuk bertemu tidak memungkinkan misalkan, teman yang jaub dari saya rumahnya."

Selanjutnya ketika dihadapkan pada pilihan dalam melakukan hubungan sosial yang dilihat lebih bermakna, sebagian besar informan (87\%) menyatakan bahwa bagi dirinya pertemuan langsunglah yang lebih bermakna. Sementara itu hanya terdapat 3\% informan yang berpandangan bahwa SMS/telepon lebih bermakna dan 10\% informan yang memandang bahwa semua cara (melalui pertemuan langsung, telepon/SMS dan melalui internet) sama-sama bermakna. Uniknya, tidak ada yang menjawab bahwa hubungan sosial melalui internet lebih bermakna.

Pandangan informan bahwa hubungan langsung lebih bermakna ini didukung oleh beberapa alasan, seperti: (i) dalam kebudayaan lingkungannya, bertemu langsung dianggap lebih sopan; (ii) makna komunikasi lebih mudah diketahui dan kesalahpahaman lebih mudah dihindari, seperti dengan memperhatikan ekspresi; (iii) bertemu secara langsung akan lebih diingat; (iv)

165 | SDSIOGLLBAL : Jurnal Pemikiran dan Penelitian Sosiologi, Vol. 4, №. 2, Juni 2020 
dapat lebih akrab dan kenal dekat dengan orang lain. Sementara interaksi sosial tak langsung melalui internet maupun telepon dan SMS juga memiliki kelebihan seperti; (i) menjadi pendukung setelah pertemuan langsung, dan; (ii) menjadi solusi ketika ruang dan waktu tidak memungkinkan interaksi langsung.

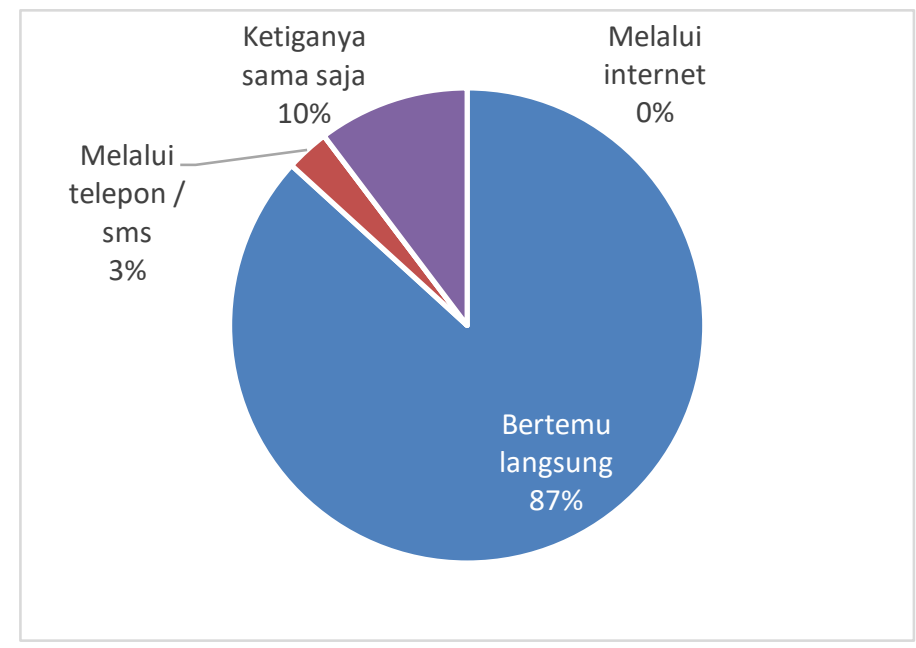

Diagram 3. Hubungan Sosial yang Lebih Bermakna Sumber : Penelitian, 2018

Uniknya, meski lebih menyukai interaksi sosial secara langsung, kondisi berbeda ditemukan ketika generasi milenial banten bertemu orang baru dan berniat menghubunginya. Sebagian besar dari mereka lebih memilih untuk menanyakan nomor whatsapp, yaitu sebanyak 42,6\% informan. Sementara yang memilih jawaban lainnya yaitu menanyakan akun facebook $(4,4 \%)$, akun line $(4,4 \%)$, nomor telepon $(23,5 \%)$ dan alamat rumah (17,6\%). Dengan begitu, terdapat dua jawaban yang terkait dengan nomor telepon, yaitu akun whatsapp dan nomor telepon, yang jika diakumulasi sebesar 66,2\%. Namun begitu, ketika ditanya lebih jauh apakah mereka menghafal nomor telepon, ditemukan bahwa hanya $24 \%$ informan yang menghafal nomor telepon keluarga, guru maupun teman sebaya.

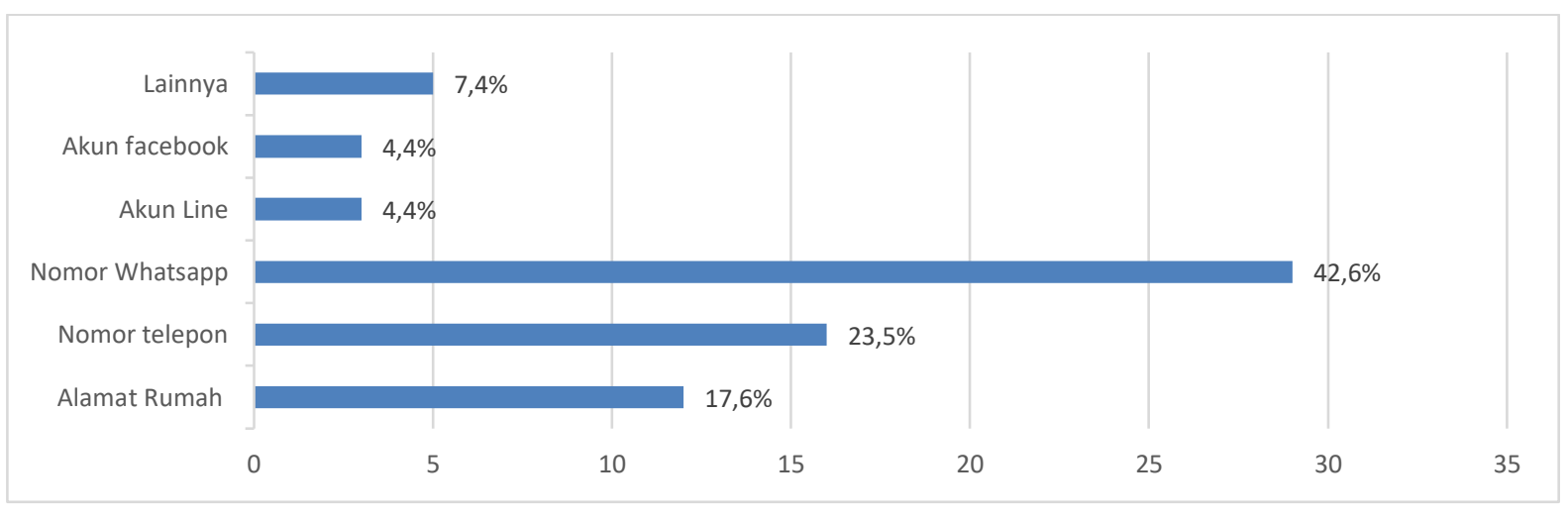

Grafik 4. Pertanyaan Sarana Komunikasi Ketika Bertemu Orang Baru Sumber : Penelitian, 2018 


\section{Relasi Kelompok Generasi Milenial Banten: Berkelompok dan Aktif dalam Kelompok}

Seperti halnya temuan Oblinger, D., dkk (2005:26), penelitian ini menemukan bahwa generasi milenial Banten pada umumnya lebih senang untuk bekerja secara berkelompok. Oblinger mengungkap bahwa generasi milenial merupakan komunikator yang produktif, mereka condong ke arah kegiatan yang mempromosikan dan memaksa interaksi sosial. Generasi ini menampilkan keterbukaan terhadap keragaman, perbedaan, dan berbagi; dan mereka merasa nyaman bertemu orang asing di Internet. Generasi ini telah mengembangkan mekanisme inklusivitas yang tidak harus melibatkan secara pribadi mengenal seseorang yang diterima di grup mereka. Menjadi teman seorang teman bisa diterima. Mereka berusaha melakukan interaksi dengan orang lain, baik dalam kehidupan pribadi, kehadiran online, atau di kelas. Temuan baru penelitian ini adalah pada kedalaman informasi yang digali, di mana penelitian ini juga mencari tahu alasan informan lebih suka berkelompok, serta mengenai persepsi informan atas pandangan orang lain terhadap dirinya.

Hasil penelitian menunjukkan bahwa 75\% informan lebih senang bekerja dalam kelompok, $23,5 \%$ lebih senang bekerja secara individual, dan 1,5\% yang lebih menyukai cara lainnya. Informan yang lebih menyukai bekerja dalam kelompok didasari oleh beberapa alasan seperti; (i) hasilnya akan lebih baik karena merupakan sinergi beragam pemikiran; (ii) pekerjaan lebih cepat selesai karena dikerjakan bersama-sama; (iii) antar individu saling membantu yang menguatkan solidaritas; (iv) menambah pengalaman dan pengetahuan; (v) memacu diri untuk lebih aktif, dan; (vi) lebih menyenangkan.

Sementara informan yang lebih menyukai bekerja secara individual didasari oleh beberapa alasan seperti; (i) dapat lebih fokus dan serius karena tidak ada yang mengganggu ketika mengerjakan sesuatu sehingga hasilnya lebih baik; (ii) karena ketika bekerja dalam kelompok seringkali ada anggota yang kurang serius, pasif dan hanya ikut serta saja.

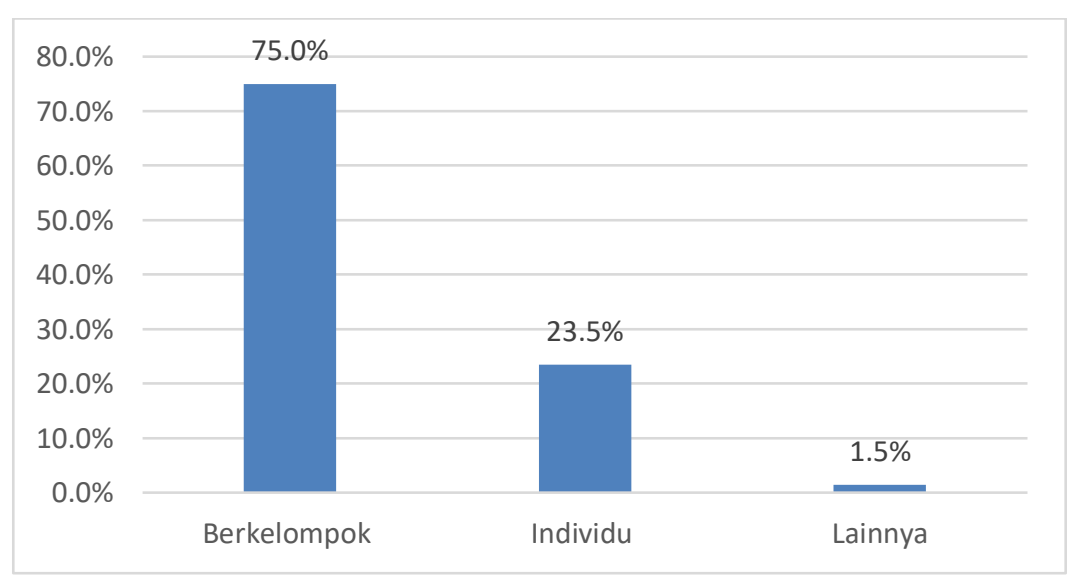

Grafik 5. Pilihan Lingkungan Kerja

Sumber : Penelitian, 2018

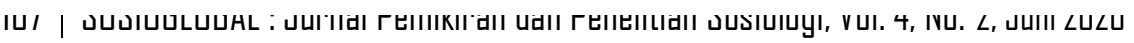


Lebih jauh lagi jika dilihat dari pengetahuan individu atas persepsi orang lain terhadap dirinya ketika bekerja dalam kelompok ditemukan bahwa $43 \%$ informan berpandangan bahwa orang memiliki persepsi bahwa dirinya biasa saja dalam aktivitas kelompok, $42 \%$ informan berpandangan bahwa orang memiliki persepsi bahwa dirinya aktif dalam aktivitas kelompok, $12 \%$ informan berpandangan bahwa orang memiliki persepsi bahwa dirinya sangat aktif dalam aktivitas kelompok, dan hanya 3\% informan berpandangan bahwa orang memiliki persepsi bahwa dirinya tidak aktif dalam aktivitas kelompok (diagram 4).

Penelitian ini juga mencari tahu bagaimana kepedulian individu terhadap pandangan orang lain terhadap dirinya. Penelitian ini memberikan pertanyaan terbuka berupa "Bagaimana kepedulian Anda dengan apa yang orang lain lihat terhadap diri ataupun perilaku Anda?”. Kemudian dilakukan kategorisasi jawaban untuk menghasilkan data visual yang ringkas.

Pada kategori jawaban memiliki kepedulian terhadap pandangan orang lain terdapat $42,6 \%$ informan, di mana kategori ini terdiri dari: (i) memiliki kepedulian terhadap apa yang orang lain lihat terhadap diri maupun perilakunya; (ii) senang terhadap pandangan orang lain terhadap dirinya karena dengan pandangan tersebut diketahui kekurangan yang harus diubah sebagai bahan introspeksi diri; (iii) ingin membangun kepekaan terhadap perasaan orang lain dengan bersikap sopan dan berikan kasih sayang; (iv) sebagai bentuk timbal balik dengan apa yang orang lain lihat; (v) memiliki pandangan bahwa komentar orang lain adalah cerminan diri; (v) memiliki kepedulian yang tinggi sampai mengganggu aktivitas jika mendapatkan pandangan buruk; (vi) memandang bahwa komentar dapat membangun diri untuk memperbaiki sisi negatif diri dan meningkatkan sisi positif pribadi.

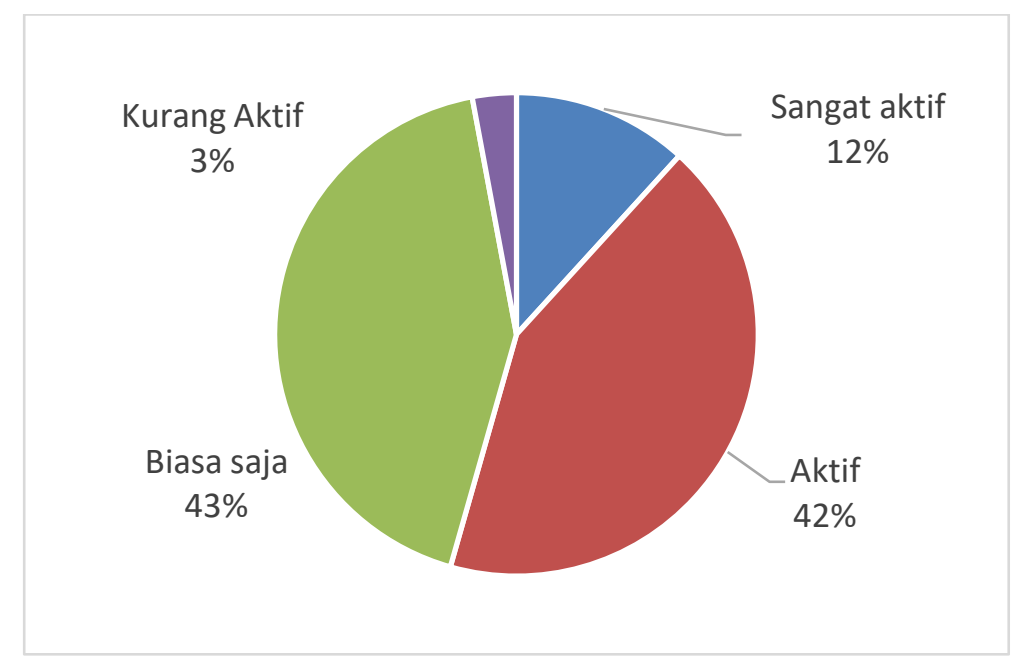

Diagram 4. Pandangan terhadap Individu dalam Kelompok Sumber : Penelitian, 2018 
Pada kategori jawaban kurang atau tidak memiliki kepedulian terhadap pandangan orang lain terhadap perilaku maupun dirinya terdapat $38,2 \%$ informan, di mana kategori ini terdiri dari: (i) tidak peduli, yang terpenting adalah dengan menjaga perilaku; (ii) biasa saja dengan apa yang orang lain lihat terhadap diri ataupun perilaku; (iii) mengabaikan pandangan orang lain tanpa perlu dihiraukan; (iv) karena sudah beranjak dewasa harus tahu mana yang saya pedulikan atau tidak.

Pada kategori jawaban bergantung pada pandangan orang lain terhadap perilaku maupun dirinya terdapat 17,6\% informan, yang secara detail kategori ini terdiri dari: (i) menerima tanggapan baik/positif dan menjadikannya sebagai motivasi, namun menghiraukan tanggapan negatif; (ii) bergantung pada urgensi pandangan orang lain terhadap dirinya tidak menanggapi penilaian orang yang buruk, dan; (iii) mendengarkan jika sarannya baik.

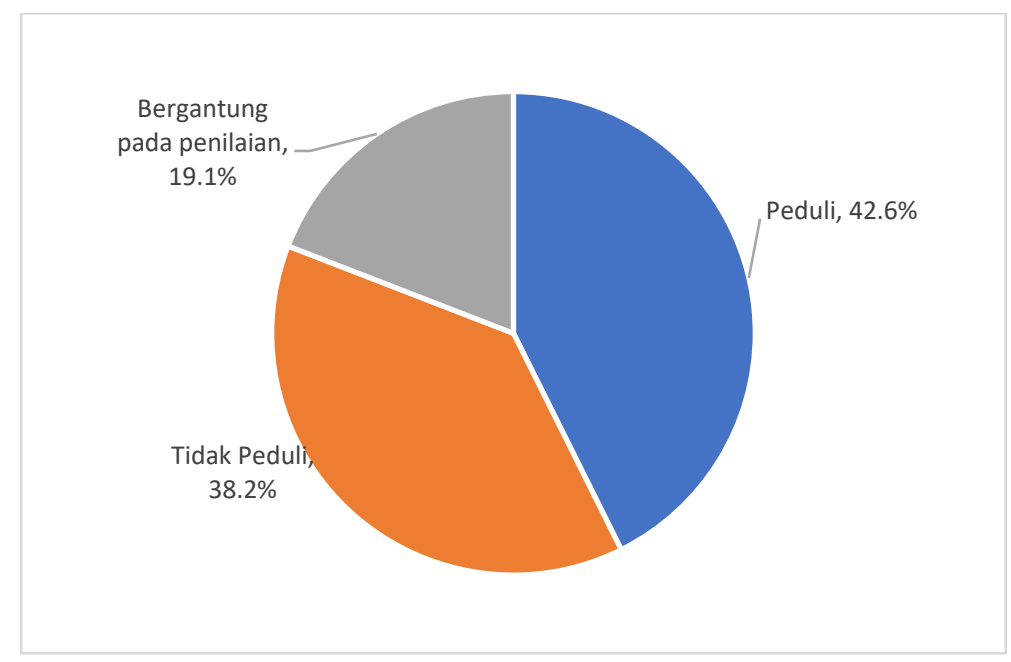

Diagram 5. Kepedulian terhadap Pandangan Masyarakat mengenai Diri ataupun Perilaku Sumber : Penelitian, 2018

Dengan demikian hasil penelitian menunjukkan bahwa karakteristik relasi sosial generasi milenial Banten tidak sama persis dengan gambaran generasi millenial. Sebagaimana Prensky (2001) yang melihat bahwa generasi milenial senantiasa terhubung dengan internet, mengutamakan kehidupan sosial (dalam dunia digital); senang belajar dan bekerja dalam tim. Karena selain pemaknaan bahwa interaksi sosial langsung lebih bermakna, generasi milenial Banten juga menyukai aktivitas komunal dan juga aktif dalam kegiatan kelompok yang dilakukan dalam dunia fisik (bukan di ruang gyberspace).

Salah satu eksplanasi mengenai interaksi tatap muka yang masih lebih disukai generasi millenial Banten dapat ditemukan pada karya Turner. Di mana Turner menemukan bahwa interaksi tatap muka masih bersifat utama dan primer di tengah posmodernitas. Memang saat ini orang dapat melakukan interaksi secara instrumental tanpa melihat orang lain, dan bahkan bisa dilakukan 
secara lebih pribadi melalui teknologi non-visual. Namun seringkali individu gagal melihat (membayangkan seperti apa rupa mereka dan isyarat visual apa yang diberikan) orang lain, padahal semakin banyak emosi yang timbul dalam suatu interaksi, semakin banyak kita mencoba untuk memvisualisasikan ekspresi wajah dan gerakan tubuh orang lain. Bahkan ketika media visual, seperti konferensi video, telah menyediakan gambaran orang lain, gambar-gambar ini sering terlalu kasar untuk pembacaan emosi yang terstruktur; kita bisa melihat orang itu, tetapi indera visual kita masih tidak dapat mendeteksi semua informasi yang secara alami kita rasakan ketika bertindak dalam situasi tatap muka langsung secara fisik yang nyata. Sejauh mana teknologi akan berkembang dalam menghasilkan gambar yang lebih menyeluruh tentang orang lain sulit untuk diprediksi, tetapi diperlukan pengembangan teknologi yang lebih memenuhi kebutuhan tersebut. Karena itu individu lebih senang melakukan kontak visual dengan orang lain secara langsung, terutama dengan mereka yang memiliki keterkaitan emosional (Turner 2002: 1-4).

\section{SIMPULAN}

Penelitian ini menemukan bahwa karakteristik generasi milenial di tingkat lokal Banten tidak sepenuhnya sama dengan karakteristik literasi digital maupun relasi sosial yang menjadi arus utama pandangan masyarakat luas maupun yang dijadikan dasar pengambilan kebijakan. Sebagaimana beberapa peneliti terdahulu yang menemukan bahwa bahwa generasi ini menampilkan variasi karakteristik dari setiap kelompok demografis, ekonomi, sosial dan lainnya (Manuel 2002:198, Budiati, I. (dkk) 2018:18). Begitu Pula dengan penelitian ini yang memiliki subjek terbatas generasi milenial yang saat ini merupakan siswa SMA kelas XI dan XII, sehingga memiliki kemungkinan perbedaan temuan jika dilihat pada rentang usia yang berbeda. Dengan begitu perlu dilakukan evaluasi secara menyeluruh atas keputusan perubahan yang menyandarkan diri pada generalisasi karakteristik generasi. Penelitian ini juga perlu diperluas cakupannya ataupun direplikasi di beberapa daerah guna melihat kondisi nyata karakteristik generasi pada setiap wilayah di Indonesia.

Hasil penelitian menemukan bahwa generasi milenial Banten memiliki karakteristik dasar literasi digital: (1) generasi milenial Banten mengandalkan buku sebagai sumber informasi; (2) bentuk visual informasi mulai dari yang paling disukai generasi milenial Banten ialah video; (3) gaya membaca generasi milenial Banten yang terbanyak adalah dengan menggunakan kata kunci atau fokus tertentu; (4) strategi verifikasi informasi generasi milenial Banten adalah dengan membandingkan sumber. Sementara pada karakteristik relasi sosial generasi milenial Banten ditemukan bahwa generasi milenial Banten lebih menyukai interaksi langsung dalam melakukan 
interaksi sosial, dan generasi milenial lebih menyukai aktivitas komunal dan aktif dalam kegiatan kelompok.

Namun begitu, meski penelitian ini menggambarkan bahwa kehadiran generasi milenial tidak sepenuhnya berkaitan dengan penggunaan perangkat digital yang masif dan kemampuan literasi digital yang tinggi, dampak dari perkembangan era digital mustahil dihindari. Terdapat tiga pilihan yang dapat kita ambil sebagai respon atas era digital, yaitu: (i) menerima penuh asumsi kehidupan masyarakat digital telah berlangsung di seluruh wilayah Indonesia, dan melakukan adaptasi secara keseluruhan; (ii) menentang kehadiran era digital dengan membatasi ataupun melarang beragam penggunaan perangkat digital maupun akses internet; (iii) melakukan adaptasi selektif berupa kompromi atas beberapa perubahan yang disebabkan kehadiran era digital.

Menolak tiga pilihan tersebut berarti membiarkan perubahan sosial berjalan tak terarah dan terencana dengan hanya mengandalkan kemampuan adaptasi masyarakat. Sebaliknya, mengambil pilihan pertama meningkatkan probabilitas pengabaian terhadap masyarakat yang tidak sepenuhnya larut dalam era digital. Kondisi Indonesia yang berupa negara kepulauan dengan bangsa yang kaya akan keragaman budaya dan kehidupan sosial serta perbedaan tingkat kesejahteraan dan lajur modernisasi mengisyaratkan pilihan ketiga yang paling layak dipilih. Yaitu dengan melakukan adaptasi sesuai dengan kondisi kehidupan digital masyarakat lokal, dan lebih baik lagi dengan memperhatikan sampai pada komunitas-komunitas yang ada di masyarakat. Juga mengenai bidang yang melakukan penyesuaian, karena kondisi kehidupan sosial, ekonomi, dan budaya di tingkat daerah acapkali tidak berjalan secara linier bersama-sama.

\section{DAFTAR PUSTAKA}

Ali, H., Purwandi, L., Nugroho, H., Ekoputri, A., \& Halim, T. (2017). The Urban Middle-Class Millenials Indonesia: Financial and Online Behavior. Jakarta: PT. Alvara Strategi Indonesia. Retrieved June 21, $2020 \quad$ (https://alvara-strategic.com/wpcontent/uploads/whitepaper/The-Urban-Middle-Class-Millenials.pdf).

Badan Pengembangan dan Pembinaan Bahasa, Kementerian Pendidikan dan Kebudayaan Republik Indonesia. 2016. Kamus Besar Babasa Indonesia (KBBI) daring. Retrieved June 21, 2020 (https://kbbi.kemdikbud.go.id/).

Barni, M. 2019. Tantangan Pendidik Di Era Millennial. JURNAL TRANSFORMATIF (ISLAMIC STUDIES), 3(1), 99-116. doi: 10.23971/tf.v3i1.1251

Bennett S., Maton K. \& Kervin L. 2008. 'The 'Digital Natives' Debate: A Critical Review of the Evidence". British Journal of Educational Technology 39, 775-786. doi: 10.1111/j.14678535.2007.00793.x

Budiati, I. (dkk). 2018. Statistik Gender Tematik: Profil Generasi Milenial Indonesia. Jakarta: Kementerian Pemberdayaan Perempuan dan Perlindungan Anak. Retrived June 21, 2020 (https://www.kemenpppa.go.id/lib/uploads/list/9acde-buku-profil-generasimilenia.pdf).

171 | SGSIOGLLBAL : Jurnal Pemikiran dan Penelitian Sosiologi, Vol. 4, No. 2, Juni 2020 
Durkheim, Emile. 1913 (1984). The Division of Labour in Society. Trans. W. D. Halls, intro. Lewis A. Coser. Macmillan, Basingstoke.

Eshet-Alkalai, Y. 2004. Digital Literacy: A Conceptual Framework for Survival Skills in the Digital era. Journal of Educational Multimedia and Hypermedia, 13(1), 93-106. Norfolk, VA: Association for the Advancement of Computing in Education (AACE). Retrieved June 21, 2020 (https://www.learntechlib.org/primary/p/4793/).

Eshet-Alkalai, Y., \& Chajut, E. 2009. Changes over time in digital literacy. CyberPsychology \& Behavior, 12(6), 713-715. doi:10.1089/cpb.2008.0264

Fajriani, S. W., \& Sugandi, Y. S. 201). Hijrah Islami Milenial Berdasarkan Paradigma Berorientasi Identitas. Sosioglobal: Jurnal Pemikiran dan Penelitian Sosiologi,3(2), 76-88. doi:10.24198/jjg.v3i2.21643

Fatmawati, N. 2019. Literasi Digital, Mendidik Anak di Era Digital bagi Orang Tua Milenial. Madani Jumal Politik Dan Sosial Kemasyarakatan, 11(2), 119-138. Retrieved June, 212020 (http://e-jurnal.unisda.ac.id/index.php/MADANI/article/view/1602)

Gilster, Paul. 1997. Digital Literacy. New York: Wiley.

Howe, N., \& Strauss, W. 2000. Millennials rising: The next great generation. Vintage.

2003. Millennials go to college: Strategies for a new generation on campus: Recruiting and admissions, campus life, and the classroom. Washington, DC: American Association of Collegiate Registrars and Admissions Officers.

Manuel, K. 2002. Teaching information literacy to generation. Journal of library administration, 36(1-2), 195-217. doi:10.1300/J111v36n01_12.

Marx, K. 1987 (1967). Capital: A Critique of Political Economy, Vol. I, trans. Moore, S, Aveling, E, ed. Engels, F . New York, NY: International Publishers.

Meyers, E. M., Erickson, I., \& Small, R. V. (2013). Digital literacy and informal learning environments: an introduction. Learning, media and technology, 38(4), 355-367.

Oblinger, D., Oblinger, J. L., \& Lippincott, J. K. 2005. Educating the net generation. Boulder, Colo.: $\begin{array}{llll}\text { Educause. } & \text { Retrieved } & \text { May } & 020\end{array}$ (https://net.educause.edu/ir/library/pdf/pub7101.pdf)

Oh, Eunjung, and Thomas C. Reeves. 2013. "Generational Differences and the Integration of Technology in Learning, Instruction, and Performance." Pp. 819-828 in Handbook of Research on Educational Communications and Technology. New York, NY: Springer New York. doi:10.1007/978-1-4614-3185-5_66.

Osterman, Mark D. 2012. "Digital Literacy: Definition, Theoretical Framework, and Competencies." in Proceedings of the 11th Annual College of Education \& GSN Research Conference (pp. 135-141). Miami: Florida International University. Retrieved May 01, 2020 (https://digitalcommons.fiu.edu/sferc/2012/2012/6/).

Prenksy, M. 2001. Digital natives, digital immigrants. On the Horizon . MCB University Press, Vol. 9 No. 5, October 2001.

Setiawan, R. 2017. "Kebebasan Ekspresi Individual dalam Pembangunan Manusia Era Digital." Pp. 169-78 in Prosiding Seminar Nasional Pendidikan FKIP UNTIRTA 2017. Retrieved May 01, 2020 (http://jurnal.untirta.ac.id/index.php/psnp/article/view/169-178).

2019. Membangun Kembali Pembelajaran Sosial Kearifan Lokal sebagai Upaya Preventif Bencana. In Talenta Conference Series: Local Wisdom, Social, and Arts (LWS A) (Vol. 2, No. 1, pp. 94-101). doi:10.32734/lwsa.v2i1.624

Simmel, G., 1978. The Philosophy of Money, trans. by T. Bottomore and D. Frisby. London: Routledge \& Kegan Paul.

Stefani, S. Nurbani, \& Badarrudin. 2017. Literasi Digital dan: Studi Korelasi Penggunaan Media 
Sosial Pada Pelajar Remaja di Kota Medan. Sosioglobal: Jurnal Pemikiran Dan Penelitian Sosiologi, 2(1), 10-31. doi:10.24198/jsg.v2i1.15268

Stolley, K. S. 2005. The basics of sociology. New York: Greenwood Publishing Group.

Sutrisno, B. 2017. Resensi Buku Digital Sociology. Sosioglobal: Jurnal Pemikiran dan Penelitian Sosiologi, 2(1), 84-86. doi:10.24198/jsg.v2i1.15273

Turkle, Sherry. 2011. Alone Together: Why we expect more from technology and less. New York: Basic Books.

Turner, J. H. (2002). Face to face: Toward a sociological theory of interpersonal behavior. Stanford University Press.

Weber, M., In Gerth, H., \& Mills, C. W. 1946. From Max Weber: Essays in sociology. New York: Oxford University Press. 